\title{
Seismic Analysis (Non-linear Static Analysis (Pushover) and Nonlinear Dynamic) on Cable - Stayed Bridge
}

\author{
Mohammad Taghipour ${ }^{1}$, Hesamoldin Yazdi ${ }^{2}$ \\ ${ }^{1}$ Department of Industrial Engineering, Science \& Research Branch of Islamic Azad University, Tehran, Iran \\ ${ }^{2}$ Civil engineering, non-profit institution of higher education, Aba - Abyek, Qazvin, Iran
}

Email address:

mohamad.taghipour@srbiau.ac.ir (M. Taghipour), hesamyazdi18@yahoo.com (H. Yazdi)

\section{To cite this article:}

Mohammad Taghipour, Hesamoldin Yazdi. Seismic Analysis (Non-linear Static Analysis (Pushover) and Nonlinear Dynamic) on Cable - Stayed Bridge. American Journal of Civil Engineering. Vol. 3, No. 5, 2015, pp. 129-139. doi: 10.11648/j.ajce.20150305.11

\begin{abstract}
Pushover analysis application development is greatly increased in recent years and numerous advanced methods to evaluate the seismic pushover are provided. Because these methods have been proposed mainly for building structures and given the fundamental differences between the behavior of bridge structures and buildings using pushover methods on the bridge structure with the uncertainties faced. 1. First, the effect of non-linear pushover results (time history) 2 . Choose a target displacement due to the finite element model should be examined in order to understand the prediction of the seismic capacity. Thus a pushover analysis is presented for evaluation of seismic bridge pylons and deck where the effects of displacement and deformation of the plastic joints, structural changes in the modal characteristics of change used plastic forms and effects of higher modes can be seen clearly. The method is able to accurately approximate the dynamic response of the nonlinear analysis. Ultimately this method compared with analysis time history.
\end{abstract}

Keywords: Seismic Analysis, Non-linear Static Analysis, Non-linear Dynamic Analysis, Cable Stayed Bridge

\section{Introduction}

Cable-stayed bridge represents key points of the transport networks and, consequently, they are thoughts to remain nearly elastic under the design seismic action, typically dampers to control the response as located in seismic-prone areas. However, several cable-stayed bridges are in Greece, Brazil, US and China also allow some structural damage in the towers in order to reduce response uncertainties under unexpectedly large earthquakes. There are many cable-stayed bridges without seismic devices which are exposed to large earthquakes and elastic design. By this method ductility demand along the towers is acceptable, and it is used to give the elastic response of the deck. Non-Linear Response History Analysis is undoubtedly the most rigorous methodology to deal with inelasticity in dynamic design, this type of analysis with responding to the ambiguities of non-linear static analysis is a complete method. The model, design and analysis in non-linear dynamic are in accordance to the local and international regulations. As this method is complex and time-consuming, non-linear static analysis as occurred at short time, can be a good alternative instead of non-linear dynamic analysis. In recent years, researchers have attempted to use non-linear static analysis instead of using non-linear dynamic analysis and several seismic design guidelines were published. Their main goal is to estimate the nonlinear seismic response by static calculations, and it means pushing the structure up to certain target displacement using load patterns reducing the computational cost drastically.

In design regulations, in Euro code 8, it is assumed that the response of a multi degree-of-freedom structure can be turned into the responses of an single degree-of-freedom model, structure response is dominated by the first mode of vibration and the single by single of these modes are combined with square root of squares, etc. and general mode of responses is achieved and this method is compared with non-linear dynamic mode. One of the results of non-linear static analysis is load-displacement chart or capacity curve achieving base shear to displacement and it is called push-over curve and with high speed of this analysis compared to other analyses, with displacement of floors and other parameters, has received much attention from engineers. Many people have work on bridge in non-linear static analysis in various pushover methods as adaptive pushover, pushover, modal pushover, etc. (Freeman et al., 1975 [1], Fajfar 1988 [2]. These studies had some limitations from that time and many discoveries have been made in this field and most of existing ambiguities in 
bridge are eliminated. In 1940, 1950, the effect of structure period on changes earthquake force on structure was discovered and interfered in structure calculations and the analysis of structures was based on its elastic response. In 1960, 1970 decades, structure ductility designs were emerged based on the evidence of tests and experiences that designed structures with good details can resist against earth movements. In decades 1980, 1990, it was shown that the damage on structure form structural member with strain and for non-structure members with relative displacement can be consistent. There is no clear relation between structure resistance and relevant damages. It seems that design of structures instead of resistance should be based on ductility and displacement. This concept develops many different seismic design methods as based on structure ductility capacity. This design method is performance-based method. IN the past two decades, many studies have been conducted on displacement-based methods and the initial years studies were mostly on reinforced concrete bridges. In recent years, these studies are generalized to different bridges. During 2005-2008, a great research team called Relous was responsible for development of guidance of design method based on displacement. To have access to study goals and performing a consistent project, 11 Universities of Italy participated in this project. Based on the review of literature, each of Universities promoted a part of this project. For example, Naply University of Italy was responsible to research about steel structures. Based on the results of this extensive project (Calvey Sullivan in 2009 [3]), draft of design code was provided based on displacement and its test version was published.

\section{Design Methods}

\section{Direct design based on displacement}

The direct design method based on displacement with the aim of eliminating the disadvantages of design method based on force was developed. The direct design is based on displacement for main structure of single degree of freedom with the same displacement is the maximum main structure and by features defined for this single degree of freedom, main multi-degree of freedom is designed. In displacement method, the goal is formation of plastic hinges in required locations and lack of formation of these hinges in other good locations. The moments and shears achieved for structure under shear force effect based on mode of first shape of vibration inelastic due to the effect of high vibration modes and conservative view in calculation of structure members should be increased to be adaptable with the real behavior of structure in earthquake. Thus, capacity design method is used to design based on displacement to increase the number of moments in plastic hinges and other locations and the shears are increased with applying some coefficients. The resistance values of distribution of shear force according to the first inelastic mode should be increased by applying extra coefficient of maximum bending capacity and amplification coefficient of the effect of higher modes to achieve from basic resistance to design resistance [4].

$$
\emptyset_{S} S_{D}=\emptyset^{\circ} S_{E}
$$

$\emptyset_{s}$ is resistance reduction coefficient and for bending moment in similar plastic hinges can be considered and for other forces and moments in other locations is smaller than 1 . For bridges in locations except plastic moment, only extra coefficient of bending strength is considered. In the design of beams, the effect of higher modes is not observed,amplificationcoefficient of higher models is not considered but due to the effect of high modes in vertical response and increase of gravity moments, this is better in exact design of capacity. For beams, both extra coefficients of bending capacity and the increasing effect of higher modes are considered. For final moments of columns and shear of columns, applying extra coefficients of bending capacity and increase of the effect of higher modes should be applied. The amplification coefficient of the effect of higher modes for moment is 1.8 and 1.3 for shear force. Generally, the design is determined based on displacement of required resistance in plastic hinges as our good goal in design is fulfilled based on displacement values and then the values of calculated resistances should be investigated by capacity design method and relevant coefficients are applied to be sure plastic hinges are not occurred in unsuitable locations and unsuitable elastic deformations to change plastic shear deformation are not occurred in structure. The general trend of design by displacement method is raised as this trend is applied for all types of structures. Single degree-of-freedom model (SDOF) is considered for frame or different types of structures and a bilinearcurve as the response of an equivalent single degree-of-freedom model to lateral force as displacement. In this chart, an initial stiffness $K_{i}$ and then stiffness after yield $r K_{i}$ are introduced. However, seismic design method introduces structure force with elastic features and before yield as initial stiffness and elastic dampingand design trend based on structure displacement is introduced with equivalent stiffness in maximum displacement and equivalent viscousdamping is a combination of elastic damping and hysteretic damping and hysteretic damping depends upon the absorbed energy by structure during elastic and cyclic behavior. As shown in Figure, equivalent viscous damping is equal to demand ductility and type of required structure of the chart [5].

By design displacement as maximum structure displacement and by equivalent viscous damping of the set of elastic displacement response spectrum charts, effective period of structure of equivalent single degree of freedom is achieved. It should be considered that maximum displacement and effective height $\mathrm{He}$ is considered. Effective stiffness $\mathrm{Ke}$ in maximum displacement is computed by following equation:

$$
K_{e}=4 \Pi^{2}\left(\frac{M_{e}}{T e^{2}}\right)
$$

The effective mass of structure in the first model is inelastic vibration and shear force is obtained as:

$$
F=K_{e} * \Delta d
$$




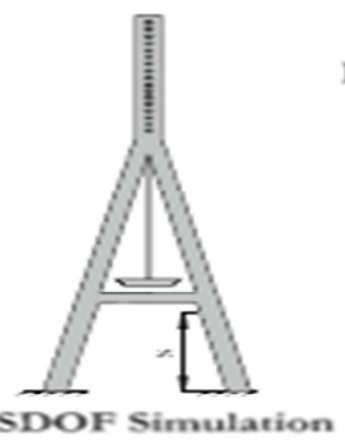

(a) SDOF Simulation

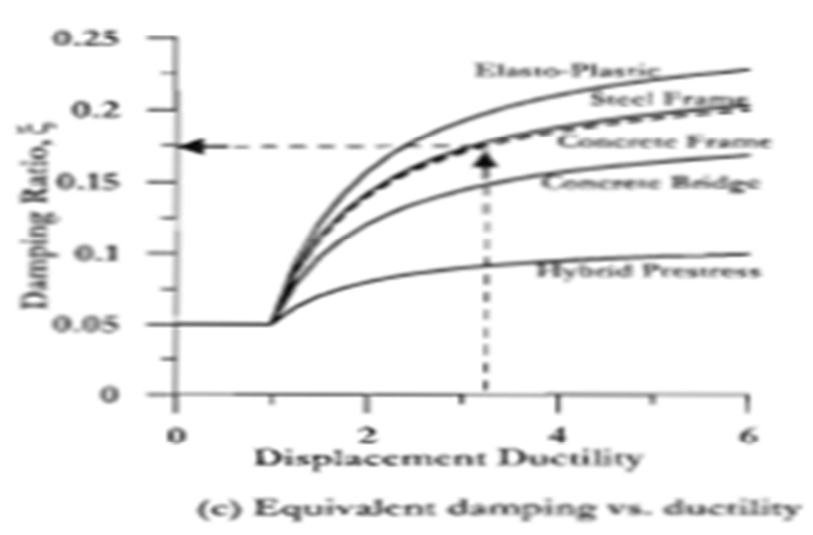

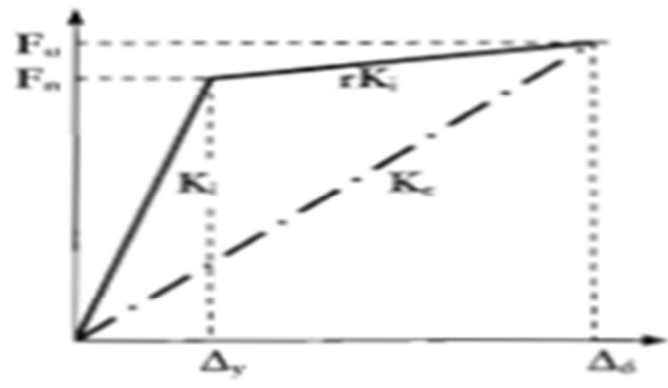

(b) Effective Stiffness $\mathbf{K}$.

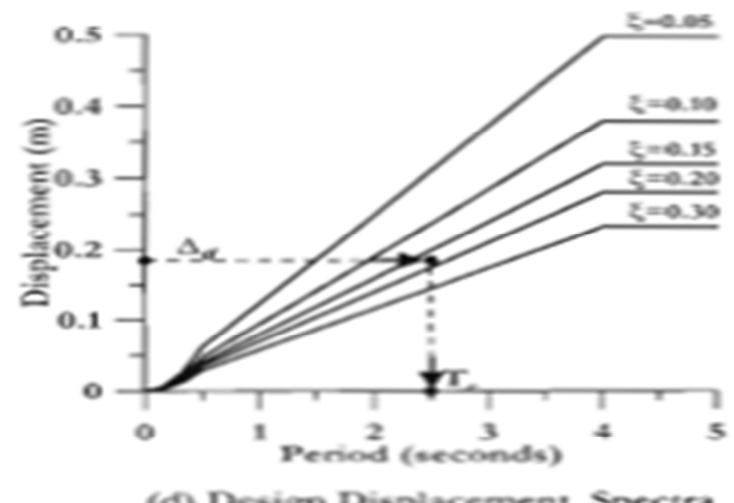

(d) Desigen Displacement Spectra

Figure 1. The stages of direct design method based on displacement [5].

\section{Non-linear Static Analysis}

Pushover static analysis

In this method, lateral load is imposed on structure gradually with a definite pattern (e.g. triangular load) and the structure is allowed to be yielded gradually (continuous yielding of various components). This loading is continued till the displacement of peak point of structure achieves target displacement. Normally, the top of structure is used as the indicator point and by achieving the roof to target displacement, analysis is stopped.
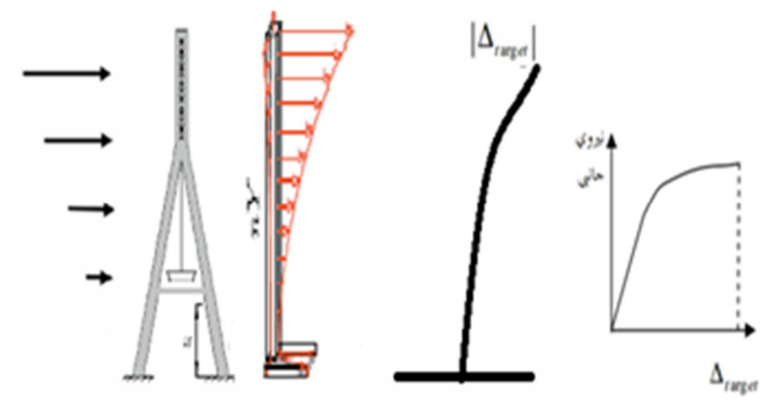

Figure 2. Pushover analysis to reach target displacement.

Total structure displacement $=$ Pushover analysis and determining force chart [6]

Target displacement based on FEMA 356 as total displacement is computed by following equation.

$$
\delta_{t}=C_{0} C_{1} C_{2} C_{3} S_{a} \frac{T_{e}^{2}}{4 \pi^{2}} g
$$

\section{Non-linear Dynamic Analysis (Time History)}

Time dynamic analysis (time history) is used to determine immediate response of structure under accelerogram and includes two different methods of elastic-linear and inelastic (non-linear). This code besides recognizing time dynamic analysis method recommends the followings: 1- The comparison of the results of elastic analysis by standard spectrum or specific design spectrum with what is achieved by elastic time dynamic analysis and the probable difference reasons are justified in a complete technical report. The response values should be modified as it was said. 2-Damping ratio in linear-elastic calculations is $5 \%$ and in non-linear calculations based on specialized recommendations and non-linearity of structure components behavior can be considered. This thesis applies New mark method for non-linear analysis of time history and average acceleration in with coefficients $\beta=0.25$ and $\alpha=0.5$ are considered. The dynamic analysis is Full Transient. In this analysis, mass matrix coefficients and stiffness matrix are computed. At first, modal analysis is done to achieve structure frequencies and then with damping assumption 5\% and using frequency of first and second model of structure and equations (Chopra 
1994), mentioned coefficients are computed [6].

$$
\left\{\begin{array}{l}
\mathrm{a}=\frac{2 \xi w_{i} w_{j}}{w_{i}+w_{j}} \\
b=\frac{2 \xi}{w_{i}+w_{j}}
\end{array}\right.
$$

\section{Modelling}

At first, cable stayed structure is divided into various parts as modeled and designed separately. Cable bridge structure includes a deck and a series of Rigid links and top and bottom pylons and beam of deck and beams of connection between pylons and concrete between Rigid link should be modeled and designed. The thickness of cables is 0.05 . The cable forms are of two types: 1- Cables kept in 1.3 above Pylon, 2- Cables divided with similar distance in the entire Pylon. In this project, bridge deck design is of great importance. The length of entire deck in this project is $320 \mathrm{~m}$ and width of deck as $22 \mathrm{~m}$ and the deck is modeled as symmetrical and the features of materials are as followings.

Table 1. The materials features for base and deck.

\begin{tabular}{ll}
\hline Concrete tensile strength & $500^{\mathrm{kg}} / \mathrm{cm} 2$ \\
Elasticity module & $335^{\mathrm{t}} / \mathrm{cm} 2$ \\
Poisson coefficient & 0.2 \\
Thermal coefficient & 0.00001 \\
\hline
\end{tabular}

The features of cables are as followings:

Table 2. Features of cables in Cable Bridge.

\begin{tabular}{ll}
\hline Nominal diameter & $\mathbf{1 5 . 7} \mathbf{m m}$ \\
\hline Nominal tensile strength & $17.7^{t} / \mathrm{cm}^{\wedge} 2$ \\
Nominal weight & $1.18 \mathrm{~kg} / \mathrm{m}$ \\
Elasticity module & $1950^{t} / \mathrm{cm} 2$ \\
Allowed tension & $0.6 u . t . s$ \\
\hline
\end{tabular}

At first, we should plot the above pylon and then bottom pylon and the beam located between bottom pylon and deck on beam, then a series of small beams as Rigid Link are perpendicular to deck beam and with joint on its start and end and some joints are dedicated to upper pylon and cables are connected top to bottom and between these connections, concrete is located and the following Figure shows the general view.

Non-linear analyses are performed on Pylon and the results are achieved.

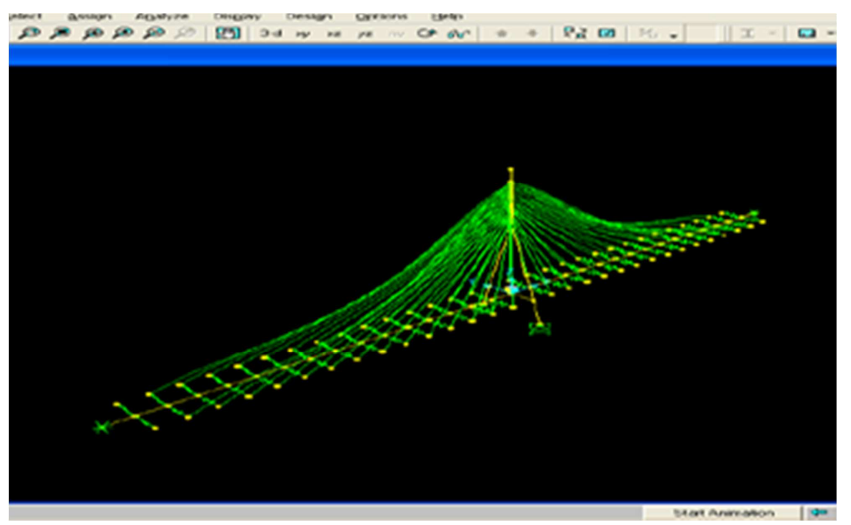

Figure 3. General view of Cable Bridge in Sap software.

\subsection{A Summary of Pushover Analysis Stages in Software}

1. Definition of plastic hinges for the members playing important role in tolerating seismic load.

2. Dedication of defined plastic hinges to relevant elements.

3. Definition of combining gravity loads based on regulation

4. Definition of lateral load patterns based on regulation.

5. Applying gravity loads combination and lateral load patterns in the combination of gravity loads by pushover analysis and evaluation of plastic hinges acceptance criteria in structure elements.

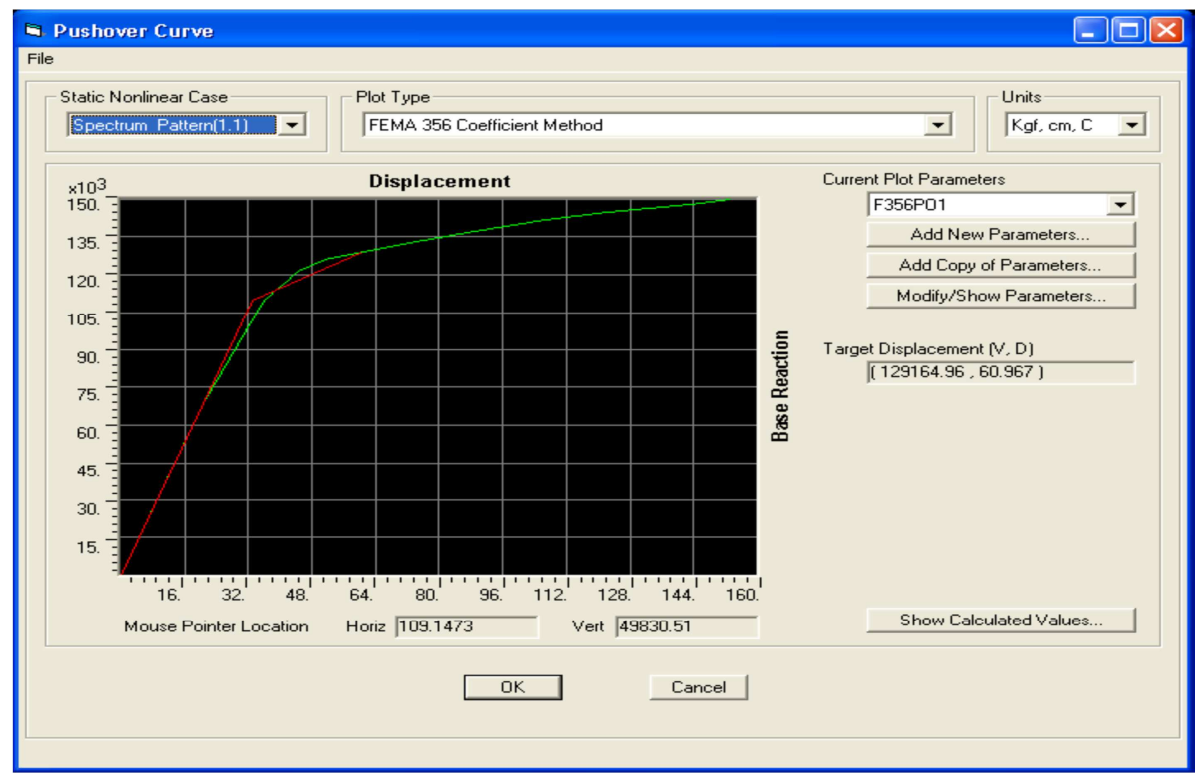

Figure 4. Capacity spectrum based on existing code (FEMA 356). 


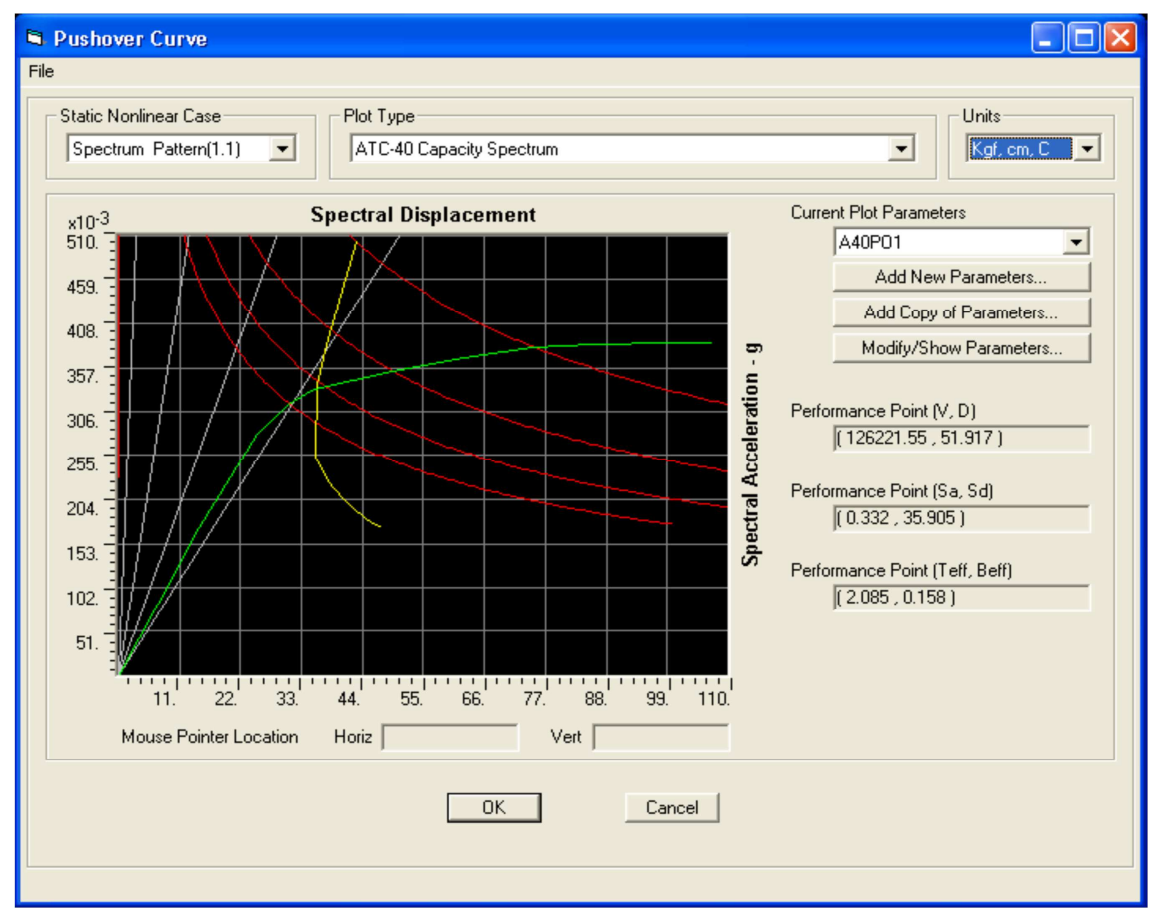

Figure 5. Capacity spectrum based on ATC440.

Based on above stages, the most important result of non-linear static analysis, capacity spectrum is achieved based on FEMA 356 and ATC 440 CODE.

As shown in the above Figure, target displacement for our cable bridge pylon is $60.96 \mathrm{~cm}$ of pushover analysis. As shown, base shear is 129.16 Ton. In this analysis, distribution of our forces is consistent with the forces of spectrum analysis. According to ATC 440, it is as followings.

As shown in the above Figure, our performance point is $51.917 \mathrm{~cm}$ and base shear is 126.22 Ton and is consistent with base shear value of FEMA 356.

The analysis of pushover with uniform load is as followings.

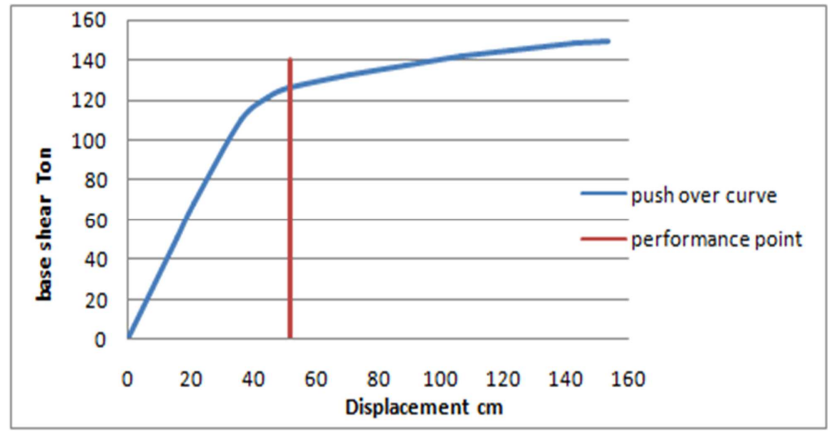

Figure 6. Determining displacement based on spectrum loading.

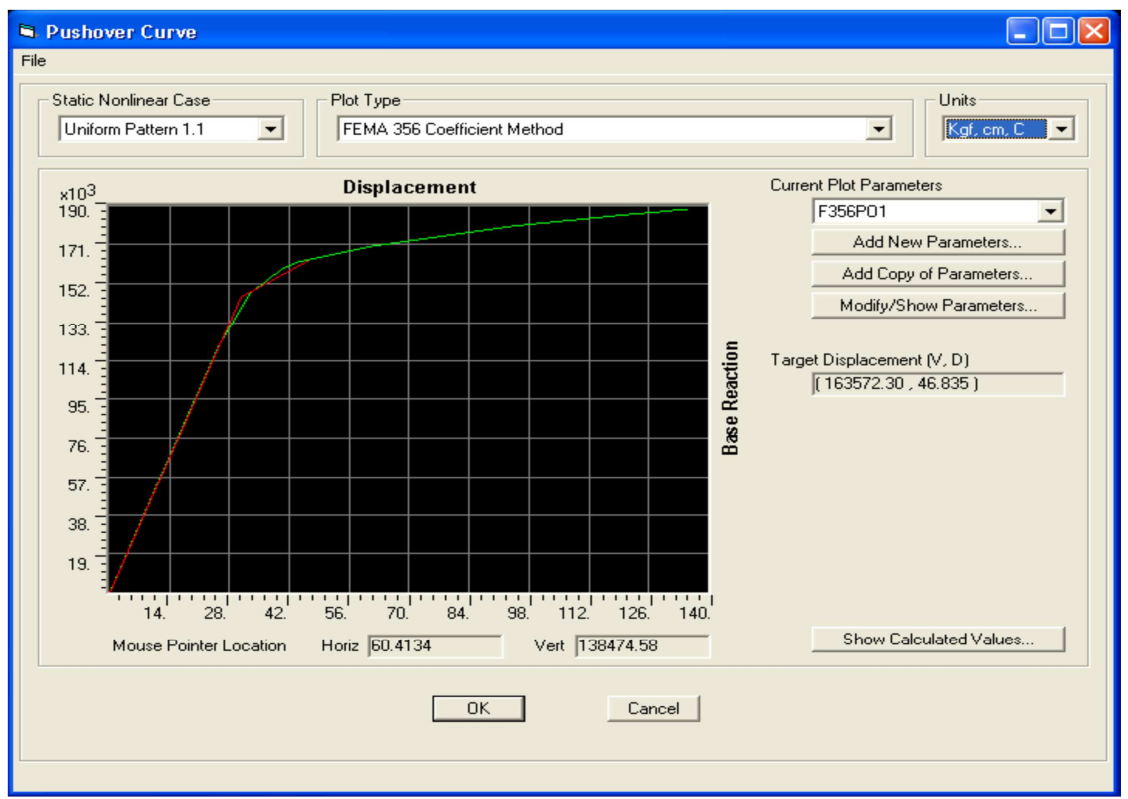

Figure 7. Capacity spectrum based on required loading in accordance to FEMA356. 
It is observed that target displacement under uniform loading of pylon is $46.83 \mathrm{~cm}$ and base shear is computed as 163.57 Ton but based on ATC440 is as followings.

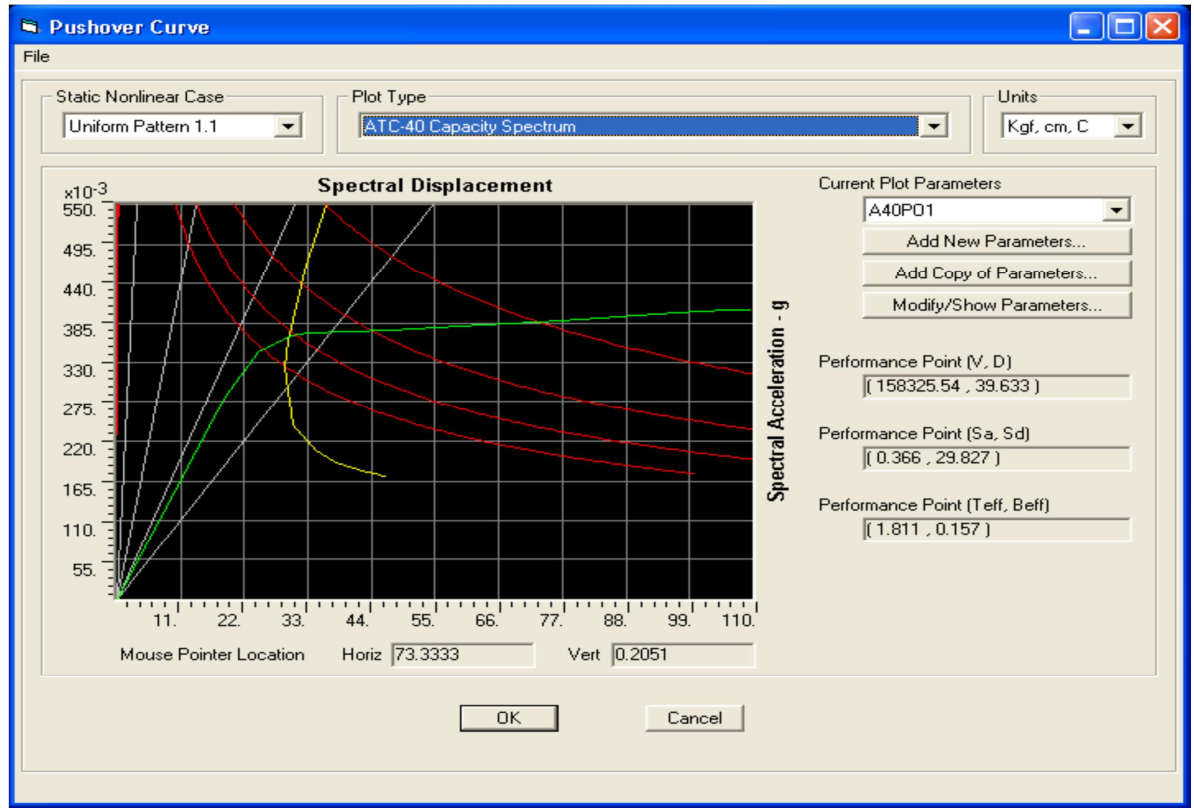

Figure 8. Capacity spectrum based on required loading in accordance to ATC 440.

Also, the performance point of uniform loading in pushover analysis is $39.63 \mathrm{~cm}$ and base shear is 158.32 Ton.

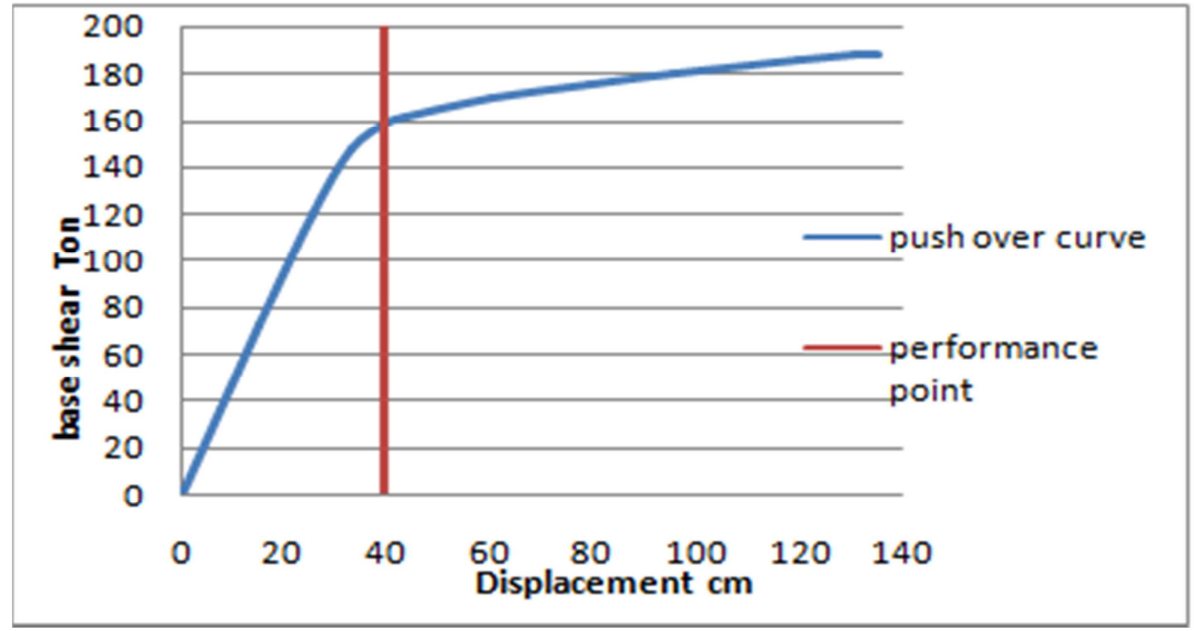

Figure 9. Determining displacement based on uniform loading.

Table 3. The comparison of the results in combination of different loads.

\begin{tabular}{|c|c|c|c|c|c|c|}
\hline \multirow[t]{2}{*}{ Case } & \multirow[t]{2}{*}{ Load combine } & \multirow[t]{2}{*}{ Load pattern } & \multicolumn{2}{|c|}{ Target displacement (FEMA) } & \multicolumn{2}{|c|}{ Performance point } \\
\hline & & & Displacement cm & Base share ton & Base shear ton & Displacement cm \\
\hline \multirow{4}{*}{ Pushover } & \multirow{2}{*}{$0.9 \mathrm{D}$} & Spectrum & 61.4 & 124 & 52 & 121 \\
\hline & & Uniform & 47.4 & 156 & 39 & 152 \\
\hline & \multirow{2}{*}{$1.1(\mathrm{D}+\mathrm{L})$} & Spectrum & 60.9 & 129 & 51 & 126 \\
\hline & & Uniform & 46.8 & 163 & 39 & 158 \\
\hline
\end{tabular}

\subsection{A Summary of the Stages of Time History Analysis in Software}

At first, some accelerograms are selected from PEER site [7] and they are scaled with acceleration $0.35 \mathrm{~g}$ and they are averaged and compared with Iran regulations. Then, records are entered into software and analysis is performed.

The applied records in time history analysis are as: 
Table 4. Applied records in time history analysis.

\begin{tabular}{llll}
\hline Record & Hour & Date & Intensity (Mercalli) \\
\hline Northridge & 12.31 & $17 / 1 / 1994$ & 6.7 \\
Kobe & 20.46 & $16 / 1 / 1995$ & 6.9 \\
\hline
\end{tabular}

At first, accelerograms are scaled to the design spectrum.

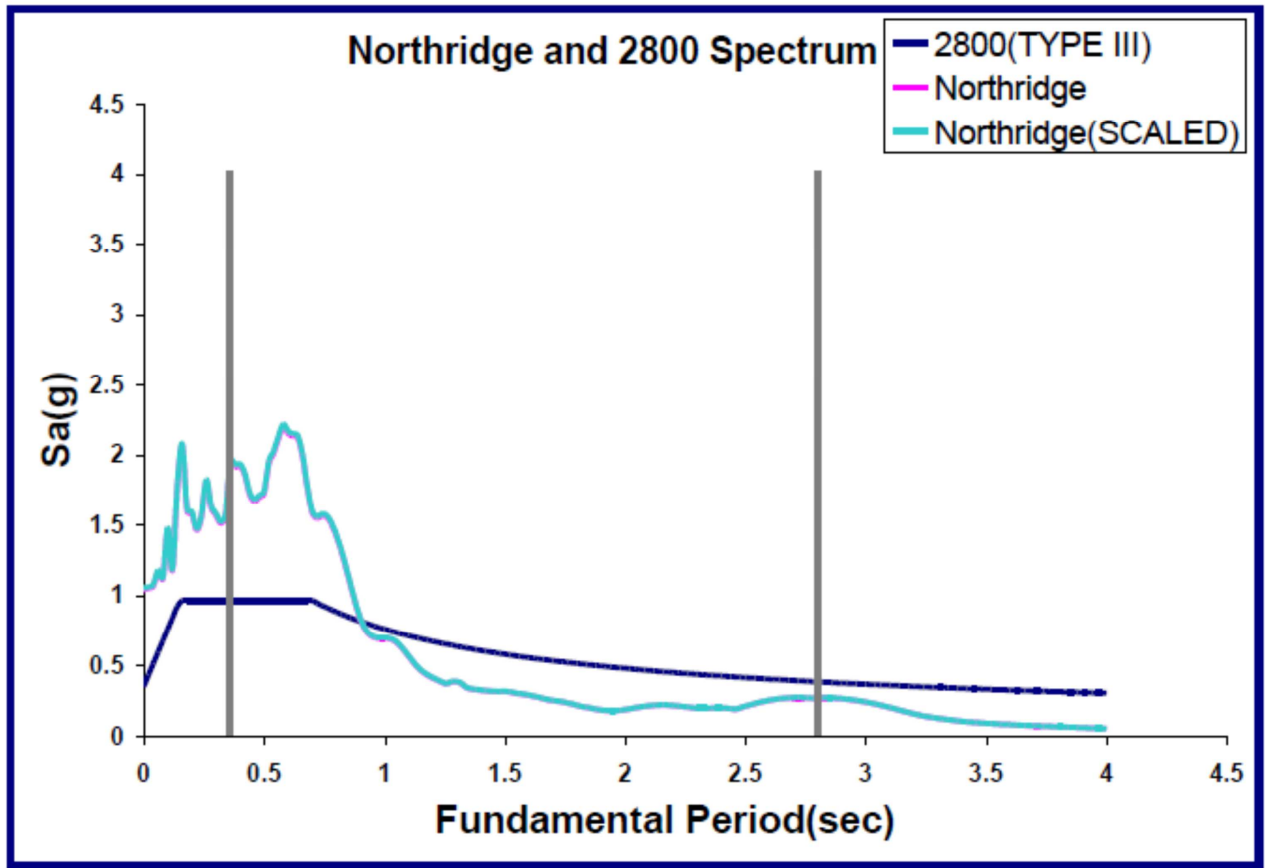

Figure 10. Scaling accelerograms with design spectrum in Northridge earthquake.

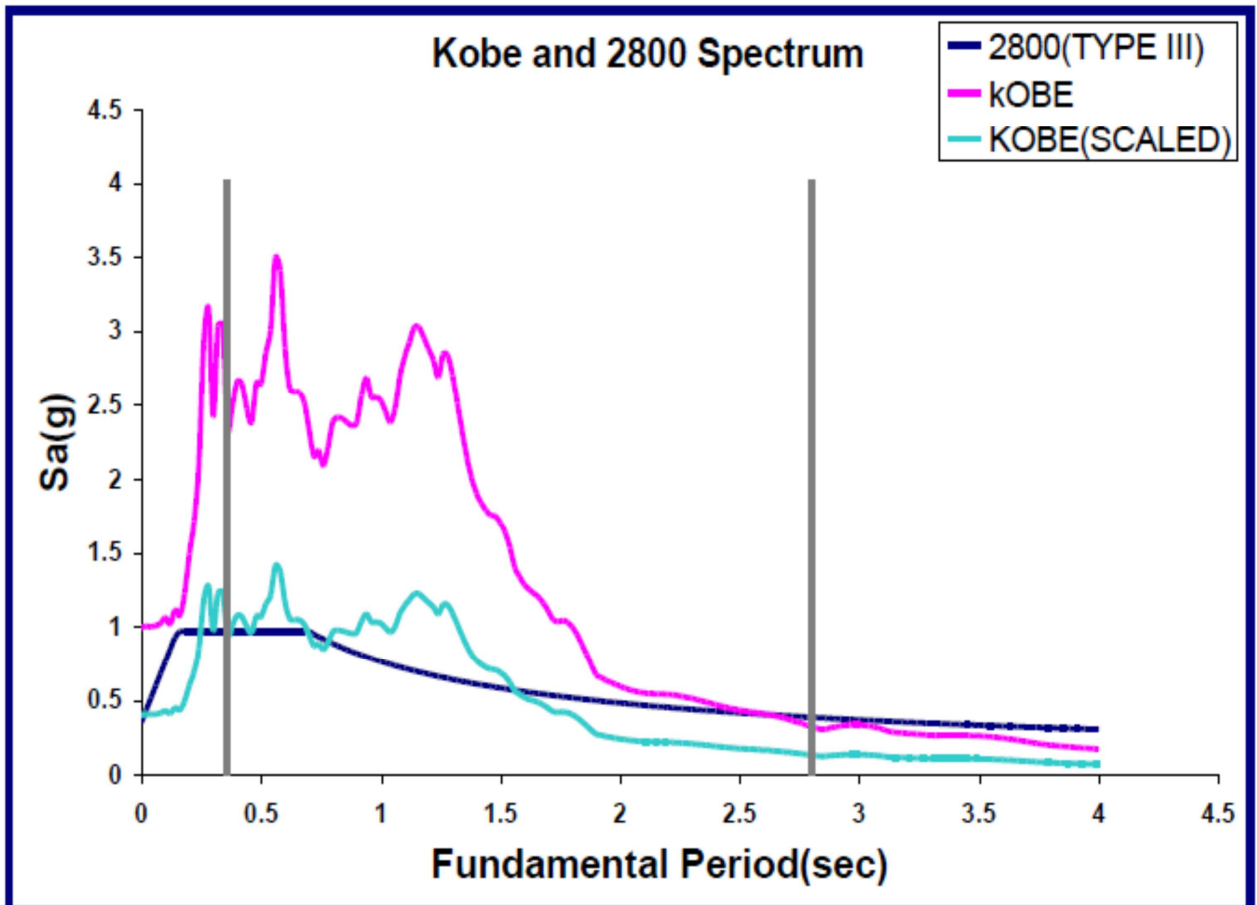

Figure 11. Scaling accelerograms with design spectrum in Kobe earthquake.

The results of time history analysis for Northridge and Kobe are shown. The time history chart of displacement of top of pylon of software is also shown. 


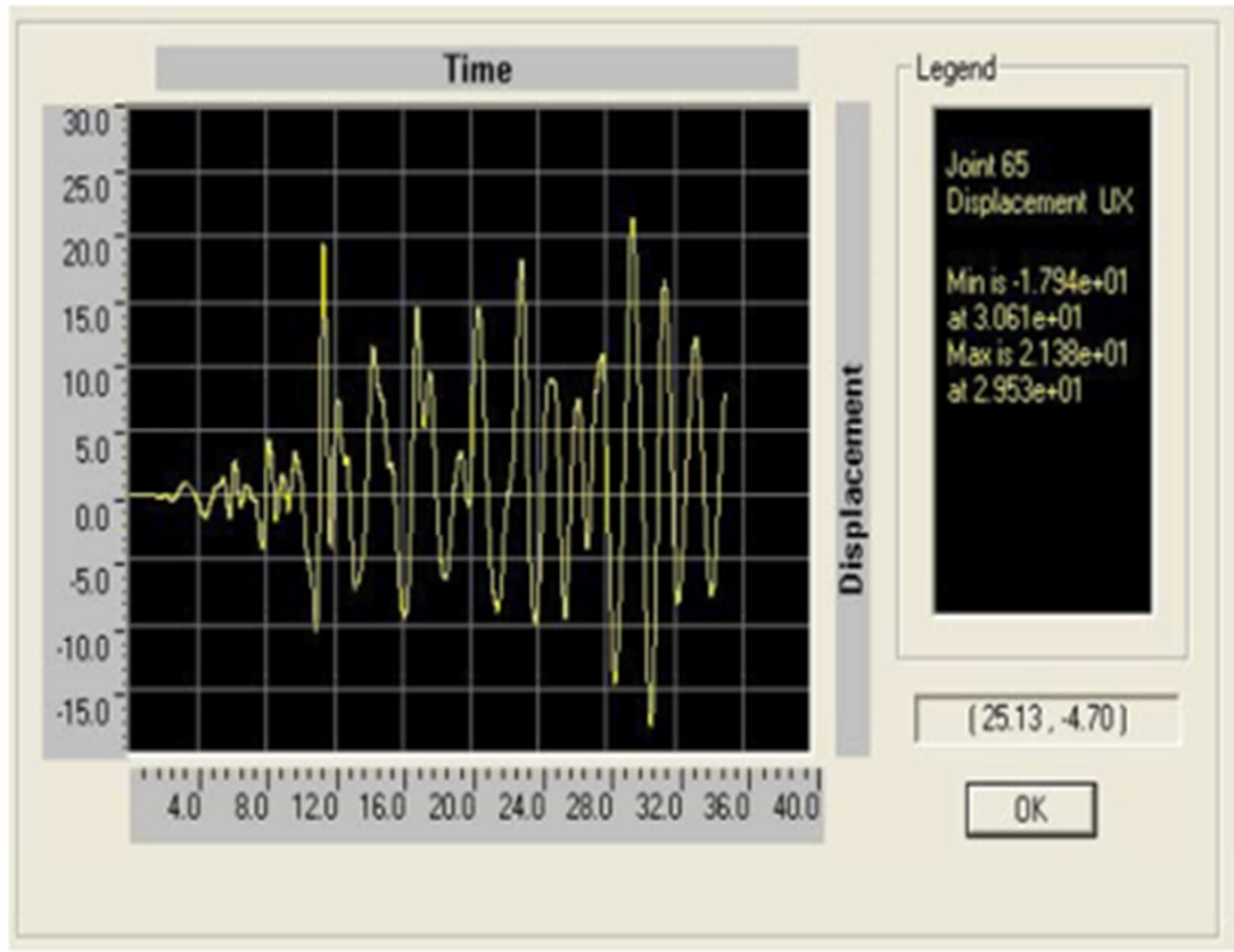

Figure 12. Displacement of top of pylon in time history analysis in Northridge earthquake.

The maximum displacement in Northridge earthquake is 31.38 but in pushover analysis, target displacement is 47.4 . Max Dis. $(31.38 \mathrm{~cm})<$ Target Displacement $(47.4 \mathrm{~cm})$

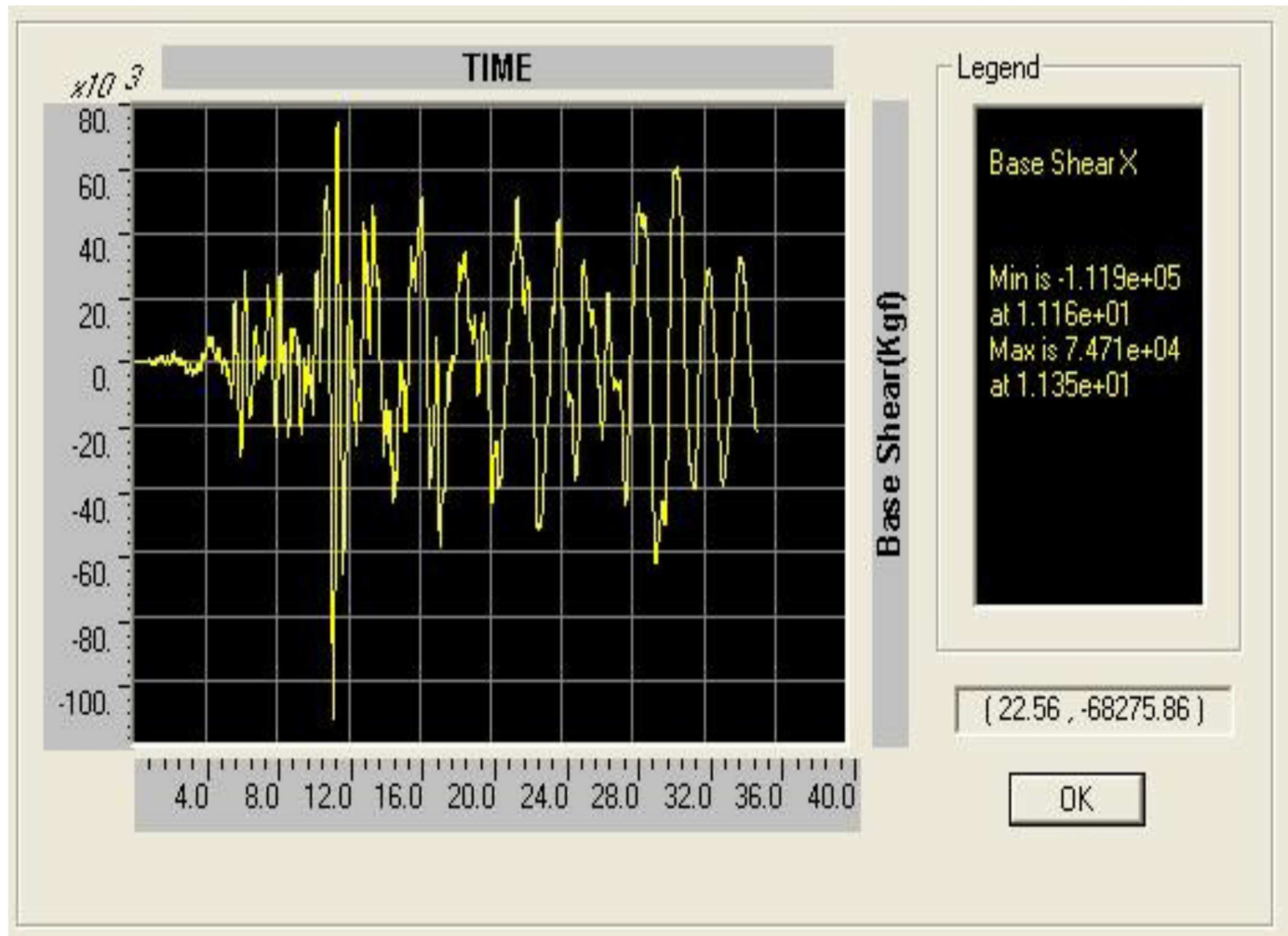

Figure 13. Base shear of top of Pylon in time history analysis in Northridge earthquake. 
In Northridge earthquake, the maximum base share is 119 Ton but in pushover analysis is 163 . By comparison of pushover analysis and time history, the following results are achieved.

Table 5. The comparison of pushover analysis displacement and time history analysis for Northridge record.

\begin{tabular}{lcccc}
\hline Load combination & $\begin{array}{l}\text { Load pattern of } \\
\text { pushover analysis }\end{array}$ & $\begin{array}{l}\text { Maximum target } \\
\text { displacement } \mathbf{( c m )}\end{array}$ & $\begin{array}{l}\text { Maximum performance } \\
\text { displacement }(\mathbf{c m})\end{array}$ & $\begin{array}{l}\text { Maximum displacement of } \\
\text { Northridge record (cm) }\end{array}$ \\
\hline \multirow{2}{*}{ 0.9D } & Spectral & 61.47 & 52.132 & 17.94 \\
& Uniform & 47.408 & 39.61 & 21.38 \\
\hline \multirow{2}{*}{ 1.1(D+L) } & Spectral & 60.96 & 51.917 & 39.63 \\
\hline
\end{tabular}

Base shear in Northridge record is as followings:

Table 6. The comparison of base shear of pushover analysis and time history analysis for Northridge record.

\begin{tabular}{lccccc}
\hline Load combination & $\begin{array}{l}\text { Load pattern } \\
\text { pushover analysis }\end{array}$ & $\begin{array}{l}\text { Maximum base } \\
\text { (Ton) FEMA }\end{array}$ & $\begin{array}{l}\text { Maximum base } \\
\text { (Ton) ATC40 }\end{array}$ & $\begin{array}{l}\text { Maximum base shear of } \\
\text { Northridge }\end{array}$ \\
\hline \multirow{2}{*}{ 0.9D } & Spectral & 124.19 & 121.86 & 74.71 \\
& Uniform & 156.57 & 152.88 & 111.9 \\
\multirow{2}{*}{ 1.1(D+L) } & Spectral & 129.16 & 126.22 & 158.32 & \\
\hline
\end{tabular}

The results in Kobe earthquake are as followings.

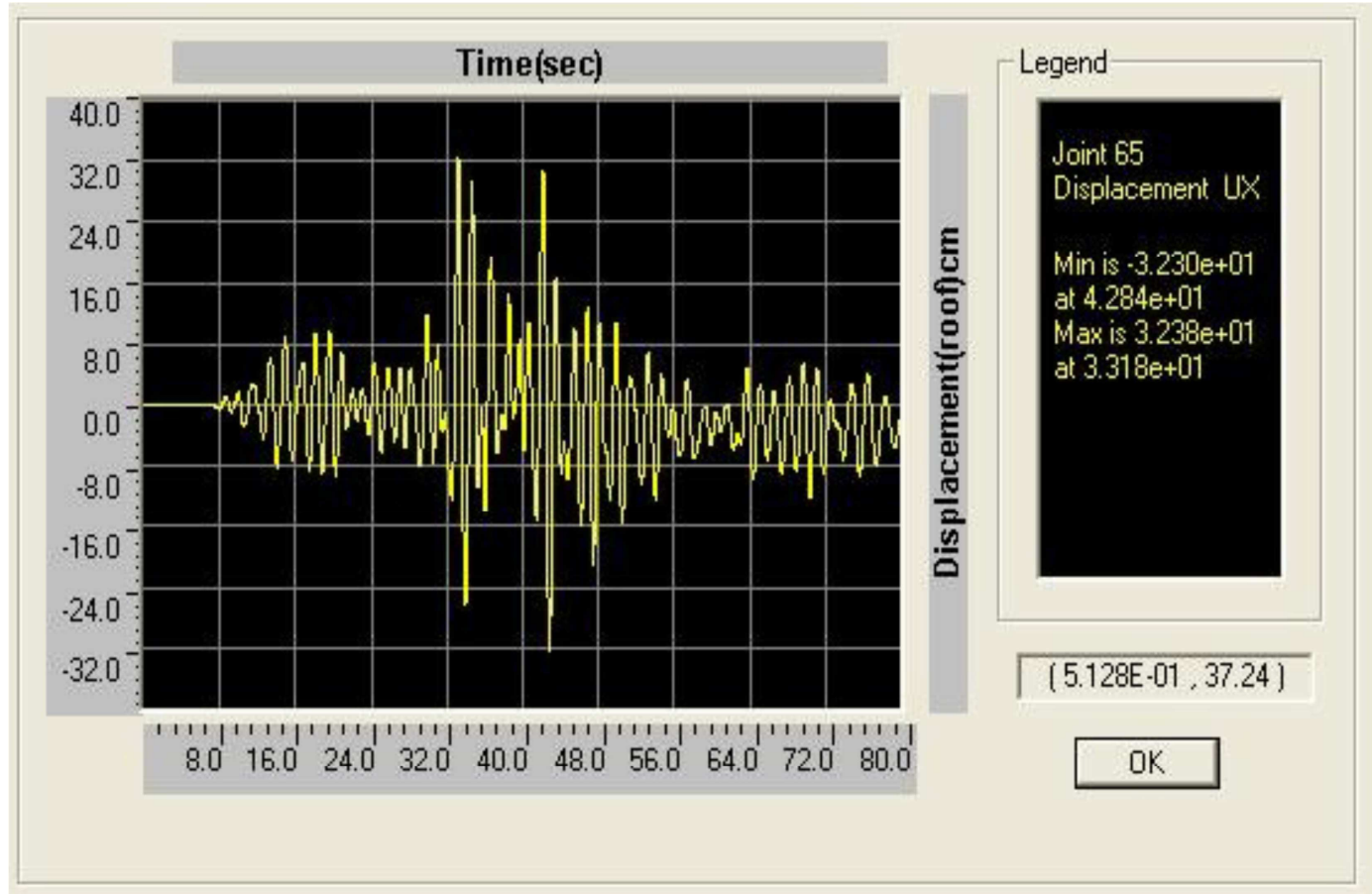

Figure 14. The displacement of top of Pylon in time history analysis in Kobe earthquake.

Maximum displacement is 33.18 and 47.4 in pushover. 


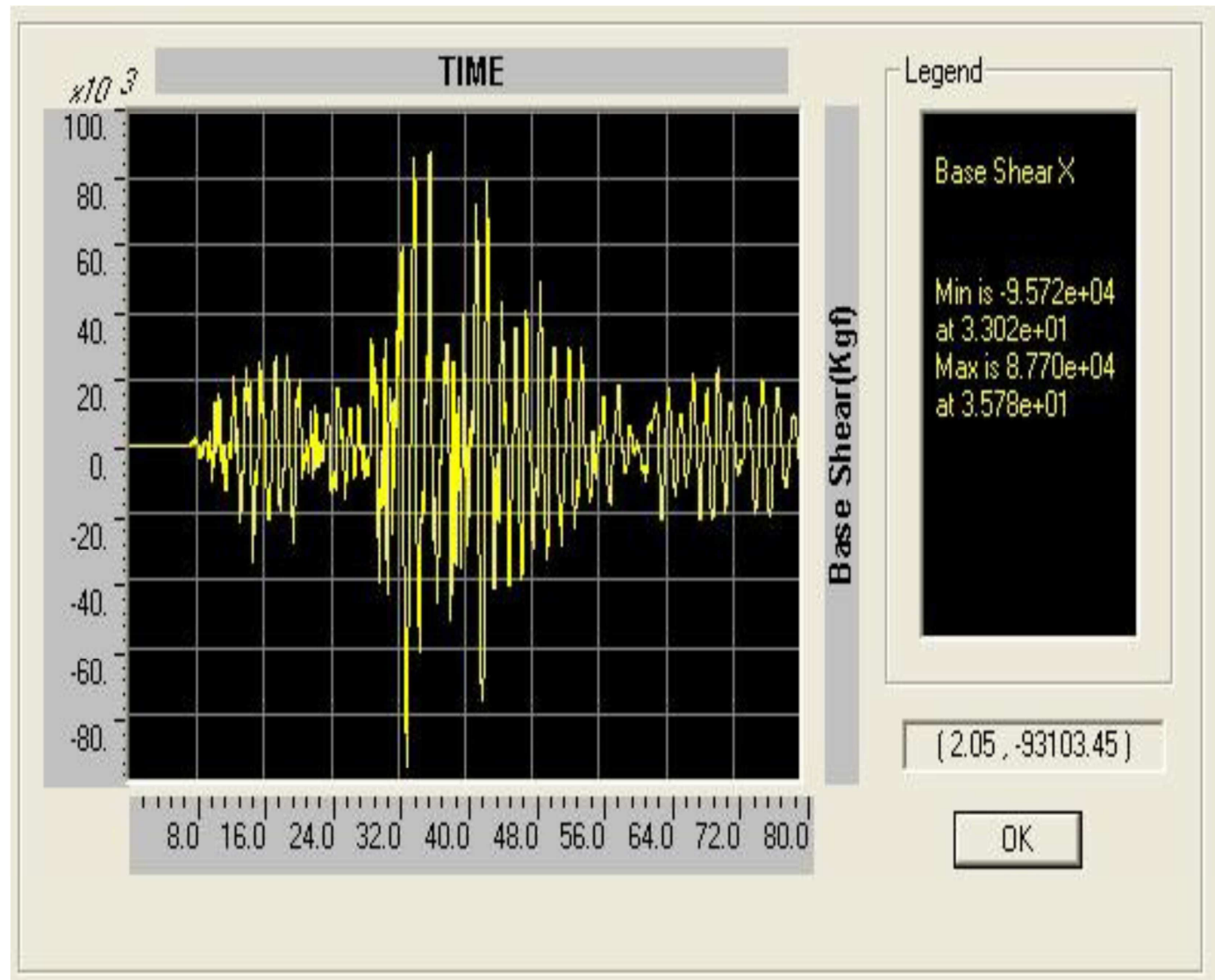

Figure 15. Base share of top of Pylon in time history analysis in Kobe earthquake.

Maximum base shear in Kobe with time history analysis 95.7 and in Pushover is 163.

Table 7. Comparison of displacement of pushover analysis and time history analysis in Kobe record.

\begin{tabular}{lccccc}
\hline Load combination & $\begin{array}{l}\text { Load pattern of } \\
\text { pushover analysis }\end{array}$ & $\begin{array}{l}\text { Maximum target } \\
\text { displacement } \mathbf{( c m )}\end{array}$ & $\begin{array}{l}\text { Maximum performance } \\
\text { displacement }(\mathbf{c m})\end{array}$ & $\begin{array}{l}\text { Maximum displacement of } \\
\text { Kobe record (cm) }\end{array}$ \\
\hline \multirow{2}{*}{ 0.9D } & Spectral & 61.47 & 52.132 & 32.3 \\
& Uniform & 47.408 & 39.61 & \\
\multirow{2}{*}{$1.1(\mathrm{D}+\mathrm{L})$} & Spectral & 60.96 & 51.917 & 32.38 \\
\hline
\end{tabular}

But base shear of Kobe record is as followings:

Table 8. Comparison of base share of pushover analysis and time history analysis of Kobe record.

\begin{tabular}{llccc}
\hline Load combination & $\begin{array}{l}\text { Load pattern of } \\
\text { pushover analysis }\end{array}$ & Maximum base shear (Ton) FEMA & $\begin{array}{l}\text { Maximum base shear } \\
\text { (Ton) ATC40 }\end{array}$ & $\begin{array}{l}\text { Maximum base shear of } \\
\text { Kobe }\end{array}$ \\
\hline \multirow{2}{*}{ 0.9D } & Spectral & 124.19 & 121.86 & 95.7 \\
& Uniform & 156.57 & 152.88 & \\
\multirow{2}{*}{$1.1(\mathrm{D}+\mathrm{L})$} & Spectral & 129.16 & 126.22 & 87.70 \\
\hline
\end{tabular}

\section{Conclusion}

The comparison of the results of non-linear static analysis and non-linear time history analysis Pylon deformation in non-linear static analysis was formed based on force distribution, based on forces of spectral analysis and uniform distribution, 2-Deformation of higher modes in non-linear static analysis for pylon is not observed, 3-The performance of cable bridge structure in proximity to target displacement for non-linear dynamic analysis based on structure performance level in non-linear static analysis with uniform lateral load. 4In non-linear static analysis with spectrum load of structure performance in target displacement with time history analysis has no consistency. 5- The required patterns of Pylon deformation distribution in static non-linear analysis are consistent with real deformations during real earthquakes. 6-The disadvantage of non-linear static analysis for evaluation 
of bridges, namely Cable Bridge is as the effect of higher modes is not considered mostly. 7-Base share of non-linear static analysis in proximity to target displacement doesn't indicate the maximum base share of non-linear dynamic analysis.

\section{References}

[1] S. A. Freeman, J. P. Nicoletti, and J. V. Tyrell, 1975, "Evaluations of Existing Buildings for Seismic Risk - A Case Study of Puget Sound Naval Shipyard, Bremerton, Washington," Proc. of the First U.S. Nat. Conf. on Earthq. Engng, Oakland,California, pp. 113-122

[2] P. Fajfar, M. Fischinger, N2 - A method for non-linear seismic analysis of regular buildings. Proc. of the 9th WCEE, August 2-9 Tokyo-Kyoto, Japan, 1988.

[3] T. J. Sullivan. (2012). Formulation of a Direct Displacement-Based Design Procedure for Steel Eccentrically Braced Frame structures.
[4] Priestly M. J. N, Kowalsky M. J, Calvi G. M. (2007). Displacment - Based Design Seismic Design of Structures. IUSS. Press:Pavia

[5] Priestly M. J. N, Kowalsky M. J, Calvi G. M. (2007). Displacment - Based Design Seismic Design Of Structures. IUSS. Press:Pavia

[6] Goel RK Chopra AK (1998). Period formulas for concrete shear wall building. Journal of Structural Engineering ASCE 124(ST4), 426-433.

[7] http://peer.berkeley.edu/

[8] Aprile A, Benedetti A, Grassucci F. Assessment of cracking and collapse for old brick masonry columns. J Struct Eng 2001;127(12):1427-35.

[9] Hern Jndez-Montes E, Kwon OS, Aschheim M. An energy-based formulation for first and multiple-mode nonlinear static (pushover) analyses. J Earthq Eng 2004;8(1):69-88.

[10] Fajfar P. A. nonlinear analysis method for performance-based seismic design. Earthq Spectra 2000. 